\title{
Effects of sodium butyrate on the growth performance, intestinal microflora and morphology of weanling pigs*
}

\author{
J.J. Lu' ${ }^{1}$ X.T. Zou and Y.M. Wang \\ Key Laboratory of Molecular Animal Nutrition, Education Ministry, \\ Feed Science Institute, Animal Science College, Zhejiang University \\ Hangzhou 310029, P.R. China
}

(Received 11 June 2007; revised version 26 June 2008; accepted 27 October 2008)

\begin{abstract}
A total of 96 pigs (Duroc $\times$ Landrace $\times$ Yorkshire) weaned at day 21 with an average initial body weight of $6.68 \mathrm{~kg}$ were used to investigate the effects of sodium butyrate on the growth performance, intestinal microflora and morphology of weanling pigs. The pigs were allocated to three dietary treatments in a randomized complete block design, each treatment was replicated four times with eight pigs per replicate and the trial lasted for 30 days. The dietary treatments were: 1 . basal diet, 2. basal diet $+500 \mathrm{mg} / \mathrm{kg}$ sodium butyrate, 3 . basal diet $+1000 \mathrm{mg} / \mathrm{kg}$ sodium butyrate. Diets were formulated according to requirements of NRC (1998) for 10-20 kg pigs. All diets were fed as mash, and no antibiotics was included. The results showed that supplementation with $1000 \mathrm{mg} / \mathrm{kg}$ sodium butyrate improved $(\mathrm{P}<0.05)$ growth performance, reduced $(\mathrm{P}<0.05)$ the total viable counts of intestinal Clostridium and Escherichia coli, decreased $(\mathrm{P}<0.05)$ tumor necrosis factor- $\alpha(\mathrm{TNF}-\alpha)$ and interleukin6 (IL-6) levels in the serum, and increased $(\mathrm{P}<0.05)$ villus height and the villus height to crypt depth ratio at the small intestinal mucosa as compared with control. The results indicated that sodium butyrate is effective in enhancing the growth and intestinal morphology of weanling pigs.
\end{abstract}

KEY WORDS: sodium butyrate, growth performance, intestinal microflora, intestinal morphology, weanling pig

\section{INTRODUCTION}

Weaning, a critical period for piglets, usually causes a large drop in feed intake resulting in severe undernutrition, which in turn results in villous atrophy and

\footnotetext{
* Supported by Science and Technology Project of Haining City, Project I 20507

${ }^{1}$ Corresponding author: e-mail: jjlu@zju.edu.cn
} 
digestive enzymes activities reduction leading to growth depression, intestinal inflammation and post-weaning diarrhoea (Lallès et al., 2004). Changes in intestine morphology and function throughout weaning have received great attention. Over the last few decades, dietary antibiotics have often been used to promote growth and control diarrhoea in piglets at weaning stage. Due to the progressive ban of dietary antibiotics, more emphasis is being placed on the development of alternatives to antibiotics for preventing diarrhoea. Today, organic acids have received much attention as an alternative and considerable research confirms positive effects on growth performance in all classes of pigs (Witte et al., 2000).

It has been suggested that the short-chain fatty acids (SCFA), which produced in the hindgut of mammals by microbial fermentation, provide an important energy source for the animal. Intestinal cells can use SCFA, particularly butyrate, as a substrate for metabolism (Jozefiak et al., 2004). Numerous studies have been on effects of butyrate on colon through total parenteral nutrition, intestine perfusion and bacterial fermentation. Butyrate produced by bacterial fermentation has been shown to inhibit mucosal apoptosis (Mentschel and Claus, 2003), induce absorption of water and sodium and proliferation of intestinal cells (Kripke et al., 1989; Friedel and Levine, 1992), and stimulate intestinal blood flow and the synthesis of gastrointestinal hormones (Mortensen et al., 1990; Mineo et al., 1994).

Some investigators have reported that addition of sodium butyrate in diets promoted the growth of weanling pigs (Galfi and Bokori, 1990; Piva and Morlacchini, 2002). Kotunia et al. (2004) found that sodium butyrate increased the small intestine development in neonatal piglets fed by artificial sow. Claus et al. (2007) reported that Ca-butyrate improved digestive and absorptive capacities in the small intestine of pigs. Because a large portion of problems at weaning stage involve the small intestine, and sodium butyrate in diets were absorbed in the fore part of the intestine (Hume et al., 1993), detailed information of effects of sodium butyrate in small intestine, may provide valuable information relevant to the maintenance of health in the young pigs. It would be of interest to investigate whether the addition of butyrate directly to diets would modify the morphology and function of the intestine, and promote the growth of weanling pigs. In the present study, we examined the effects of sodium butyrate on growth performance, intestinal microflora, and intestinal morphology of weanling pigs.

\section{MATERIAL AND METHODS}

\section{Materials, experimental design and sampling procedure}

Sodium butyrate (99.9\%) was obtained from the Huadong Medicine Company (Zhejiang Province, China). All procedures were approved by the University 
of Zhejiang Institutional Animal Care and Use Committee. A total of 96 pigs (Duroc $\times$ Landrace $\times$ Yorkshire) weaned at $\mathrm{d} 21$ with an average initial body weight of $6.68 \mathrm{~kg}$ were allocated to three dietary treatments in a randomized complete block design, each treatment was replicated four times with eight pigs per replicate and the trial lasted for 30 days. The dietary treatments were: 1 . basal diet, 2 . basal diet + $500 \mathrm{mg} / \mathrm{kg}$ sodium butyrate, 3 . basal diet $+1000 \mathrm{mg} / \mathrm{kg}$ sodium butyrate. Diets were formulated according to requirements of NRC (1998) for 10-20 kg pigs. All diets were fed as mash, and no antibiotics was included (Table 1). All pigs were given

Table 1. Ingredient and chemical composition of the basal diet on an as-fed basis

\begin{tabular}{|c|c|}
\hline Item & $\%$ \\
\hline \multicolumn{2}{|l|}{ Ingredient } \\
\hline maize & 55.7 \\
\hline soyabean meal $(45 \%)$ & 18.3 \\
\hline soyabean oil & 1.6 \\
\hline extruded full-fat soyabean & 12.0 \\
\hline fish meal $(63 \%)$ & 4.0 \\
\hline dried whey & 4.0 \\
\hline dicalcium phosphate & 2.0 \\
\hline limestone & 1.0 \\
\hline sodium chloride & 0.25 \\
\hline L-lysine $\mathrm{HCl}(78 \%)$ & 0.27 \\
\hline methionine $(98.5 \%)$ & 0.5 \\
\hline vitamin-mineral premix ${ }^{1}$ & 1.0 \\
\hline \multicolumn{2}{|c|}{ Analysed chemical composition of feed } \\
\hline $\mathrm{DE}, \mathrm{MJ} / \mathrm{kg}^{2}$ & 14.53 \\
\hline crude protein & 20.3 \\
\hline lysine & 1.33 \\
\hline Met. + Cyst. & 0.70 \\
\hline threonine & 0.90 \\
\hline calcium & 0.9 \\
\hline total phosphorus & 0.65 \\
\hline \multicolumn{2}{|c|}{ 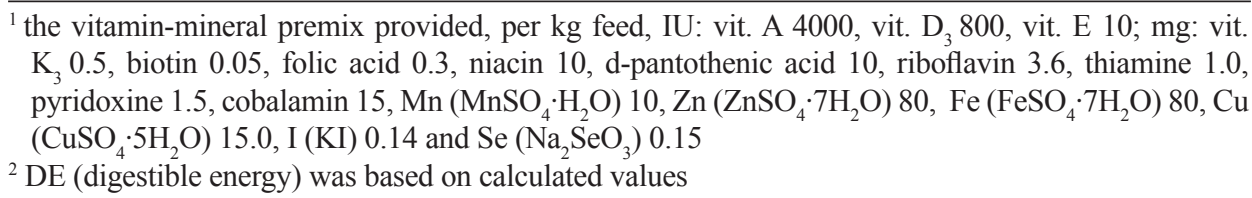 } \\
\hline
\end{tabular}

ad libitum access to feed and water. Feed intake was recorded per pen. At the start and end of the feeding trial, the pigs were weighed individually and growth performance results as average daily gain (ADG), average daily feed intake (ADFI), average gain/feed $(\mathrm{G} / \mathrm{F})$ were calculated for all pigs. 
At the end of the feeding trial eight pigs from each treatment (two pigs per pen), selected randomly based on similar body weight, were slaughtered under general anaesthesia and then immediately eviscerated. Blood samples were centrifuged at $3,000 \mathrm{rpm} / \mathrm{min}$ for $10 \mathrm{~min}$, and serum was separated and packed in eppendorf tubes, and kept at $-70^{\circ} \mathrm{C}$ until analysis. Samples of the contents from the small intestine (from the distal end of the duodenum to the ileo-caecal junction) and proximal colon were collected into glass containers under $\mathrm{CO}_{2}$, sealed and put on ice until they were transported to the lab for enumeration of microbial populations. The tissue sample from the middle part of duodenum, jejunum and ileum was excised, flushed with physiological saline and fixed in $10 \%$ formalin.

\section{Intestinal microbial populations}

Ten grams of mixed contents were blended under $\mathrm{CO}_{2}$ in $90 \mathrm{ml}$ of anaerobic dilution solution (ADS). Further, serial dilutions were made in ADS for anaerobic bacterial enumeration. The initial dilution in ADS was also used as a source for serial dilutions in phosphate buffer solution for enumeration of aerobic bacterial populations. Triplicate plates were then inoculated with $0.1 \mathrm{ml}$ samples and incubated at $37^{\circ} \mathrm{C}$ aerobically or anaerobically as appropriate. Three dilutions were plated for each medium. Bacteria were enumerated on Wilkins chalgren agar (Oxoid; total anaerobes), brain heart infusion agar (Oxoid; total aerobes), MRS agar (Oxoid; Lactobacillus), reinforced clostridial agar plus supplements (Munoa and Pares, 1988; Bifidobacterium), sulphite-polymyxin milk agar (Mevissen-Verhage et al., 1987; Clostridium), and MacConkey's no. 2 (Oxoid; E. coli). Single colonies were removed from selective media plates and grown in peptone yeast glucose (PYG) broth. Subsequently, the bacteria were characterized to genus level on the basis of colonial appearance, gram reaction, spore production, cell morphology and fermentation end-product formation (Holdeman et al., 1977).

\section{Histomorphometry}

Three cross-sections for each intestinal sample were prepared after staining with haematoxylin and eosin using standard paraffin embedding procedures. A total of 10 intact, well-oriented crypt-villus units were selected in triplicate for each intestinal cross-section (30 measurements for each sample, total of 240 measurements per dietary treatment). Villus height and crypt depth were determined using image processing and analysis system (version 1, Leica Imaging Systems Ltd., Cambridge, England). 
Measurement of tumor necrosis factor- $\alpha(T N F-\alpha)$ and interleukin-6 (IL-6) levels in serum

Levels of TNF- $\alpha$ and IL- 6 in serum were measured separately using Quantikine ELISA kits (R\&D Systems, Minneapolis, MN. 21 pg/ml detection limit for IL-6 and $5 \mathrm{pg} / \mathrm{ml}$ for TNF- $\alpha$, respectively) according to the manufacturer's instructions. The reaction was terminated with a stop buffer and absorbance read at $450 \mathrm{~nm}$ using an MRX Revelation (Dynex Technologies, Chantilly, VA) multiwell plate reader. Experiments were carried out in triplicate and results are shown as pg/ml.

\section{Statistical analysis}

All data were analysed by analysis of variances using the general linear model (GLM) procedures of SAS (version 6.12). Duncan's multiple range test was applied to treatment means which showed a statistically significant variation in the samples. Differences were considered significant at $\mathrm{P}<0.05$.

\section{RESULTS}

The growth performance of weanling pigs is presented in Table 2. Pigs fed with $1000 \mathrm{mg} / \mathrm{kg}$ sodium butyrate diets had higher $(\mathrm{P}<0.05)$ ADG, ADFI and feed conversion than those fed with control or $500 \mathrm{mg} / \mathrm{kg}$ sodium butyrate diets. Supplementation with $500 \mathrm{mg} / \mathrm{kg}$ sodium butyrate had no $(\mathrm{P}>0.05)$ effect on growth performance as compared with the control.

Table 2. Effects of sodium butyrate on growth performance of weanling pigs ${ }^{1}$

\begin{tabular}{lcccc}
\hline & Control & $500 \mathrm{mg} / \mathrm{kg} \mathrm{SB}^{2}$ & $1000 \mathrm{mg} / \mathrm{kg} \mathrm{SB}$ & $\mathrm{SEM}^{3}$ \\
\hline Initial weight, $\mathrm{kg}$ & 6.68 & 6.71 & 6.66 & 0.21 \\
Final weight, $\mathrm{kg}$ & $17.54^{\mathrm{b}}$ & $18.17^{\mathrm{b}}$ & $19.59^{\mathrm{a}}$ & 0.37 \\
ADG, g & $362^{\mathrm{b}}$ & $382^{\mathrm{b}}$ & $431^{\mathrm{a}}$ & 10 \\
ADFI, g & $510^{\mathrm{b}}$ & $524^{\mathrm{b}}$ & $565^{\mathrm{a}}$ & 18 \\
Gain : feed & $0.71^{\mathrm{b}}$ & $0.73^{\mathrm{b}}$ & $0.76^{\mathrm{a}}$ & 0.014 \\
\hline
\end{tabular}

means within a row with different letters $(\mathrm{a}-\mathrm{b})$ differ significantly $(\mathrm{P}<0.05)$ when tested with Duncan's new multiple-range test following analysis of variance; ${ }^{1}$ data are means of four replicate pens of eight pigs each; $n=32$ for $A D G, n=4$ for $A D F I$ and $F / G$ per treatment. The trial lasted 30 days; ${ }^{2} \mathrm{SB}$ - sodium butyrate; ${ }^{3}$ standard error of the mean

Intestinal microflora of weanling pigs is presented in Table 3. Supplementation with $1000 \mathrm{mg} / \mathrm{kg}$ sodium butyrate reduced $(\mathrm{P}<0.05)$ the total viable counts of Clostridium and E. coli in the small intestine and proximal colon of weanling pigs as 
Table 3. Effect of dietary sodium butyrate (SB) on intestinal microflora of weanling pigs ${ }^{1,2}$

\begin{tabular}{lcccc}
\hline Site and microflora & Control & $500 \mathrm{mg} / \mathrm{kg} \mathrm{SB}^{3}$ & $1000 \mathrm{mg} / \mathrm{kg} \mathrm{SB}$ & $\mathrm{SEM}^{4}$ \\
\hline Small intestine & & & & \\
total aerobes & 7.8 & 7.7 & 7.3 & 0.21 \\
total anaerobes & 8.9 & 9.0 & 9.0 & 0.32 \\
Bifidobacterium & 7.1 & 7.4 & 7.5 & 0.22 \\
Lactobacillus & 8.3 & 8.4 & 8.8 & 0.28 \\
Clostridium & $6.1^{\mathrm{a}}$ & $5.4^{\mathrm{ab}}$ & $5.2^{\mathrm{b}}$ & 0.32 \\
Escherichia coli & $7.3^{\mathrm{a}}$ & $6.9^{\mathrm{ab}}$ & $6.2^{\mathrm{b}}$ & 0.26 \\
Proximal colon & & & & \\
total aerobes & 9.3 & 9.2 & 9.0 & 0.31 \\
total anaerobes & 10.5 & 10.4 & 10.2 & 0.23 \\
Bifidobacterium & 7.7 & 8.1 & 8.1 & 0.22 \\
Lactobacillus & 8.6 & 9.2 & 9.4 & 0.29 \\
Clostridium & $7.4^{\mathrm{a}}$ & $7.1^{\mathrm{a}}$ & $6.3^{\mathrm{b}}$ & 0.26 \\
Escherichia coli & $8.3^{\mathrm{a}}$ & $8.1^{\mathrm{a}}$ & $7.4^{\mathrm{b}}$ & 0.19 \\
\hline
\end{tabular}

means within a row with different letters $(\mathrm{a}, \mathrm{b})$ differ significantly $(\mathrm{P}<0.05) ;{ }^{1}$ bacterial numbers are expressed as $\log 10$ colony-forming units per gram of $\mathrm{DM} ;{ }^{2}$ data are the means of four replicates of two pigs per replicate; ${ }^{3} \mathrm{SB}$ - sodium butyrate; ${ }^{4}$ standard error of the mean

compared with the control. Supplementation with $500 \mathrm{mg} / \mathrm{kg}$ sodium butyrate had no effect $(\mathrm{P}>0.05)$ on intestinal microflora as compared with control. Pigs fed with 1000 $\mathrm{mg} / \mathrm{kg}$ sodium butyrate had lower $(\mathrm{P}<0.05)$ viable counts of Clostridium and E. coli in colonic contents than those fed with $500 \mathrm{mg} / \mathrm{kg}$ sodium butyrate. The total aerobes, total anaerobes, Bifidobacterium and Lactobacillus in the small intestinal and colonic contents of pigs were not affected by the dietary treatments.

Morphological measurement of the small intestinal mucosa of weanling pigs is presented in Table 4. Supplementation with $1000 \mathrm{mg} / \mathrm{kg}$ sodium butyrate had higher $(\mathrm{P}<0.05)$ villus height and the villus height to crypt depth ratio at the small intestinal mucosa as compared with the control, and increased $(\mathrm{P}<0.05)$ villus height at the jejunum and the villus height to crypt depth ratio at the jejunum and ileum as compared with $500 \mathrm{mg} / \mathrm{kg}$ sodium butyrate. Supplementation with 500 $\mathrm{mg} / \mathrm{kg}$ sodium butyrate increased $(\mathrm{P}<0.05)$ villus height and the villus height to crypt depth ratio at the jejunum as compared with the control.

Levels of TNF- $\alpha$ and IL-6 in serum of weanling pigs is presented in Table 5. Supplementation with $1000 \mathrm{mg} / \mathrm{kg}$ sodium butyrate reduced $(\mathrm{P}<0.01)$ the levels of TNF- $\alpha$ and IL-6 in serum of weanling pigs as compared with the control or 500 $\mathrm{mg} / \mathrm{kg}$ sodium butyrate group. Supplementation with $500 \mathrm{mg} / \mathrm{kg}$ sodium butyrate reduced $(\mathrm{P}<0.05)$ the levels of TNF- $\alpha$ and IL-6 in serum of weanling pigs as compared with the control. 
Table 4. Effects of sodium butyrate (SB) on the morphology of the intestinal mucosa in different sites of the small intestine ${ }^{1}$

\begin{tabular}{lcccc}
\hline Item & Control & $500 \mathrm{mg} / \mathrm{kg} \mathrm{SB}^{2}$ & $1000 \mathrm{mg} / \mathrm{kg} \mathrm{SB}$ & SEM $^{3}$ \\
\hline $\begin{array}{l}\text { Villus height, } \mu m \\
\text { duodenum }\end{array}$ & $535^{\mathrm{b}}$ & $566^{\mathrm{ab}}$ & $616^{\mathrm{a}}$ & 21 \\
jejunum & $781^{\mathrm{c}}$ & $830^{\mathrm{b}}$ & $902^{\mathrm{a}}$ & 23 \\
$\quad$ ileum & $525^{\mathrm{b}}$ & $554^{\mathrm{ab}}$ & $601^{\mathrm{a}}$ & 21 \\
$\begin{array}{l}\text { Crypt depth, } \mu m \\
\text { duodenum }\end{array}$ & & & \\
jejunum & 364 & 347 & 339 & 18 \\
ileum & $416^{\mathrm{a}}$ & $389^{\mathrm{ab}}$ & $364^{\mathrm{b}}$ & 14 \\
$\begin{array}{l}\text { Villus height: crypt depth } \\
\text { duodenum }\end{array}$ & 323 & 321 & 316 & 17 \\
jejunum & & & & \\
$\quad$ ileum & $1.47^{\mathrm{b}}$ & $1.63^{\mathrm{ab}}$ & $1.81^{\mathrm{a}}$ & 0.08 \\
\hline
\end{tabular}

means within a row with different letters (a-c) differ significantly $(\mathrm{P}<0.05) ;{ }^{1}$ data are the means of four replicates of two pigs per replicate; ${ }^{2} \mathrm{SB}$ - sodium butyrate; ${ }^{3}$ standard error of the mean

Table 5. Effects of sodium butyrate (SB) on the levels of TNF- $\alpha$ and IL-6 in serum of weaning pigs $^{1}$

\begin{tabular}{lcccc}
\hline $\mathrm{pg} / \mathrm{ml}$ & Control & $500 \mathrm{mg} / \mathrm{kg} \mathrm{SB}^{2}$ & $1000 \mathrm{mg} / \mathrm{kg} \mathrm{SB}$ & $\mathrm{SEM}^{3}$ \\
\hline $\mathrm{TNF}-\alpha$ & $789^{\mathrm{a}}$ & $433^{\mathrm{b}}$ & $181^{\mathrm{c}}$ & 35 \\
$\mathrm{IL}-6$ & $390^{\mathrm{a}}$ & $253^{\mathrm{b}}$ & $101^{\mathrm{c}}$ & 42 \\
\hline
\end{tabular}

means within a row with different letters (a-c) differ significantly $(\mathrm{P}<0.05) ;{ }^{1}$ data are the means of four replicates of two pigs per replicate; ${ }^{2} \mathrm{SB}$ - sodium butyrate; ${ }^{3}$ standard error of the mean

\section{DISCUSSION}

The current results proved the beneficial effects of sodium butyrate supplementation in weanling pigs feed. In contrast to other organic acids, sodium butyrate was used in much lower concentrations $(1.0 \mathrm{~g} / \mathrm{kg})$ than citric acid, acetic acid and propionic acid $(4-20 \mathrm{~g} / \mathrm{kg})$ and could easily be mixed in the diet because it was powdery.

The present study was consistent with the previous reports in weanling pigs. Galfi and Bokori (1990) found that the diet containing 0.17\% sodium butyrate increased the ADG and feed consumption of pigs weighing $7 \mathrm{~kg}$. Piva and Morlacchini (2002) found that $800 \mathrm{mg} / \mathrm{kg}$ sodium butyrate improved growth performance of weaned piglets during the first two weeks period after weaning.

The increased ADFI was observed in pigs supplemented with $1000 \mathrm{mg} / \mathrm{kg}$ sodium butyrate in the present study. This may attribute to its regulation on the gastrointestinal 
emptying patters. In one study it was found that infusion of SCFA, including sodium butyrate, at the ileum by way of a silicon tube increased gastric emptying and intestinal motility compared to a similar infusion of saline (Malbert et al., 1994), but the exact mechanism of the effect of sodium butyrate was not clear. On the other hand, this effect may be related to the low levels of TNF- $\alpha$ and IL- 6 in serum observed in the pigs fed with $1000 \mathrm{mg} / \mathrm{kg}$ sodium butyrate. It was reported that TNF- $\alpha$ release into the cerebral ventricles potently blocks appetite, and such animals would starve to death despite free access to feed (Tracey et al., 1990). IL-6 plays a major role in the hepatic production of acute-phase reactants, and is thought to suppress linear growth by reduction of IGF-1 production (De Benedetti et al., 1997).

It is well know that intestinal contents may vary according to age of the weanling pigs. Such variability in composition of contents could affect the growth conditions of enteric microflora. Galfi and Bokori (1990) found that the diet containing $0.17 \%$ sodium butyrate markedly reduced the percentile proportion of Coliform bacteria and increased the counts of Lactobacillus in the ileum and caecum. The effect of sodium butyrate could be mainly due to its extensive biological action, not its acidification because sodium butyrate did not decrease the $\mathrm{pH}$ of the diet. Sodium butyrate might resist invasion of opportunistic bacteria, including direct inhibition of bacterial growth, and/or interference with adhesion to host tissues (Mathew et al., 1996). However, in the current study, only bacteria free in the small intestinal and colonic contents were assayed. Because some enterotoxigenic E. coli (ETEC) serogroups characteristically adhere to the gut mucosa as a prerequisite to virulence (Gaastra and De Graaf, 1982), their numbers might not be detected by the assays used in this study. Thus determination of Coliform profiles would likely require further studies that address serotypic identification of adherent $E$. coli on the mucosal lining.

The structure of the intestinal mucosa can reveal some information on gut health. The gastrointestinal mucosa maintains tissue and immune homeostasis in the presence of large numbers of enteric bacteria and their products. In the present study, an increase in villus height and villus height to crypt depth ratio at the small intestinal mucosa of the pigs supplemented with $1000 \mathrm{mg} / \mathrm{kg}$ sodium butyrate was observed. The addition of $500 \mathrm{mg} / \mathrm{kg}$ sodium butyrate to the diet also produced a positive effect on the intestinal mucosa. Such improved intestinal mucosal morphology may be explained by the changes in microfloral profiles, increased ADFI, low levels of serum cytokines (TNF- $\alpha$, IL-6) and improvement of gastrointestinal health in weanling pigs.

In addition to serve as a major energy substrate, sodium butyrate exerts potent effects on epithelial cells by regulating immune function, and contributes to the maintenance of homeostasis of the bowel mucosa (D'Argenio and Mazzacca, 1999), which include suppression of IL-8 secretion (Gibson and Rosella, 1995), and inhibition of NF- $\kappa \mathrm{B}$ activation (Inan et al., 2000). 
As one of the most potent stimuli of intestinal proliferation, the oral intake of food and its physical presence in the gastrointestinal tract per se are necessary for structural and functional maintenance of the intestinal mucosa (Kelly et al., 1992). The presence of food in the gastrointestinal tract has direct and indirect effects on epithelial cell proliferation. The absence of nutrients from the gut lumen occurs after weaning will have marked effects on the rate of cell differentiation and cell turnover. It is well recognized, for example, that the exclusion of nutrients from the lumen of the small intestine either by starvation, dietary restriction, or intravenous feeding, results in villous atrophy and a decrease in crypt-cell production rate. Since these changes have been reported in the gut of the newly-weaned pig, it is likely that luminal nutrition plays a strong role in the integrity of the structure and function of the small intestine after weaning.

In the present study, decreased TNF- $\alpha$ and IL-6 levels in serum were observed in pigs fed with 500 or $1000 \mathrm{mg} / \mathrm{kg}$ sodium butyrate. To our knowledge, the role of cytokines in the histological, biochemical and immunological changes that occur in the small intestine of the young pigs after weaning has not been explored. However, some evidences have demonstrated that serum cytokines are important regulators of intestinal immunity (Kramer et al., 1995), and major regulators of epithelial cell growth and development, including intestinal inflammation and epithelial restitution following mucosal damage. For example, Ferreira et al. (1990) showed that activation of T cells in the lamina propria of explants of foetal human small intestine caused villous atrophy and crypt hyperplasia. Similarly, Lionetti et al. (1993) demonstrated that large numbers of activated macrophages could result in villous atrophy, crypt hyperplasia and, in some cases, complete mucosal destruction. The role that such cytokine 'cross talk' between epithelial and lymphoid cells plays in either epithelial integrity or mucosal immune function is not yet fully understood.

The experiment indicated that sodium butyrate could be used to improve the morphology of intestinal epithelium, and promote digestion and absorption in weanling pigs.

\section{CONCLUSIONS}

As an endogenesis produced by microbial fermentation in the intestine, not alien to the body, and a source of high efficient energy, sodium butyrate plays an important role in promoting growth performance of weanling pigs, keeping the completeness of structure of intestinal membrane and protecting the beneficial microflora population in gastrointestinal tract. With respect to its favourable biological and economic effects, sodium butyrate can be recommended for use in weanling pigs feeding as a growth promoter. 


\section{ACKNOWLEDGEMENTS}

The authors gratefully acknowledge to Xiangjun Fang, Ming Li for their skilled technical assistance.

\section{REFERENCES}

Claus R., Günthner D., Letzguss H., 2007. Effects of feeding fat-coated butyrate on mucosal morphology and function in the small intestine of the pig. J. Anim. Physiol. Anim. Nutr. 91, 312-318

D’Argenio G., Mazzacca G., 1999. Short-chain fatty acid in the human colon. Relation to inflammatory bowel diseases and colon cancer. Adv. Exp. Med. Biol. 472, 149-158

De Benedetti F., Alonzi T., Moretta A., Lazzaro D., Costa P., Poli V., Martini A., Ciliberto G., Fattori E., 1997. Interleukin-6 causes growth impairment in transgenic mice through a decrease in insulin-like growth factor-1. A model for stunted growth in children with chronic inflammation. J. Clin. Invest. 99, 643-650

Ferreira R.C., Forsyth L.E., Richman P. I., Wells C., Spencer J., MacDonald T.T., 1990. Changes in the rate of crypt epithelial cell proliferation and mucosal morphology induced by a T-cell mediated response in human small intestine. Gastroenterology 98, 1255-1263

Friedel D., Levine G.M., 1992. Effect of short-chain fatty acid on colonic function and structure. J. Parent. Enter. Nutr. 16, 1-4

Gaastra W., De Graaf F.K., 1982. Host-specific fimbrial adhesins of noninvasive enterotoxigenic Escherichia coli strains. Microbiol. Rev. 46, 129-161

Galfi P., Bokori J., 1990. Feeding trial in pigs with a diet containing sodium n-butyrate. Acta Vet. Hung. 38, 3-17

Gibson P.R., Rosella O., 1995. Interleukin-8 secretion by colonic crypt cells in vitro: a response to injury that is suppressed by butyrate and enhanced in inflammatory bowel disease. Gut 37 , 536-543

Holdeman L.V., Cato E.P., Moore W. E.C. (Editors), 1977. Anaerobic Laboratory Mannual. 4th Edition. Virginia Polytechnic Institute and State University, Blacksburg, pp. 51-70

Hume M.E., Corrier D.E., Ivie G.W., Delosch J.R., 1993. Metabolism of [14C] propionic acid in broiler chicks. Poultry Sci. 72, 786-793

Inan M.S., Rasoulpour R.J., Yin L., Hubbard A.K., Rosenberg D.W., Giardina C., 2000. The luminal short-chain fatty acid butyrate modulates NF- $\mathrm{kB}$ activity in a human colonic epithelial cell line. Gastroenterology 118, 724-734

Jozefiak D., Rutkowski A., Martin S.A., 2004. Carbohydrate fermentation in the avian ceca: a review. Anim. Feed Sci. Tech. 113, 1-15

Kelly D., King T.P., McFadyen M., Travis A.J., 1991. Effect of lactation on the decline of brush border lactase activity in neonatal pigs. Gut 32, 386-392

Kotunia A., Wolinski J., Laubitz D., Jurkowska M., Romé V., Guilloteau P., Zabielski R., 2004. Effect of sodium butyrate on the small intestine development in neonatal piglets feed by artificial sow. J. Physiol. Pharmacol. 55, Suppl. 2, 59-68

Kramer D.R., Sutherland R.M., Bao S., Husband A.J., 1995. Cytokine mediated effects in mucosal immunity. Immun. Cell Biol. 73, 389-396

Kripke S.A., Fox A.D., Berman J.M., 1989. Stimulation of intestinal mucosal growth with intracolonic infusion of short-chain fatty acids. J. Parent. Enter. Nutr. 13, 109-116 
Lallès J.P., Boudry G., Favier C., Le Floc'h N., Luron I., Montagne L., Oswald I.P., Pié S., Piel C., Sève B., 2004. Gut function and dysfunction in young pigs: physiology. Anim. Res. 53, 301316

Lionetti P., Breese E., Braegger C.P., Murch S.H., Taylor J., MacDonald T.T., 1993. T-cell activation can induce either mucosal destruction or adaptation in cultured human fetal small intestine. Gastroenterology 105, 373-381

Malbert C.H., Montfort I., Mathis C., Guerin S., Laplace J.P., 1994. Remote effects of ile-colic SCFA levels on gastric motility and emptying. In: Proceedings of 6th International Symposium on Digestion Physiology in Pigs. Bad Doberan (Germany), pp. 283-286

Mathew A.G., Franklin M.A., Upchurch W.G., Chattin S.E., 1996. Effects of weaning on ileal shortchain fatty acid concentrations in pigs. Nutr. Res. 16, 1689-1698

Mentschel J., Claus R., 2003. Increased butyrate formation in the pig colon by feeding raw potato starch leads to a reduction of colonocyte apoptosis and a shift to the stem cell compartment. Metabolism 52, 1400-1405

Mevissen-Verhage E.A.E., Marcelis J.H., deVos N.M., Verhoef J., 1987. Bifidobacterium, Bacteroides and Clostridium spp. in faecal samples from breast-fed and bottle-fed infants with and without iron supplement. J. Clin. Microbiol. 25, 285-289

Mineo H., Hashizume Y., Hanaki Y., Murata K., Maeda H., Onaga T., Kato S., Yanaihara N., 1994. Chemical specificity of short-chain fatty acids in stimulating insulin and glucagons secretion in sheep. Amer. J. Physiol. 267, E234-E241

Mortensen F.V., Nielsen H., Mulvany M.J., Hessov I., 1990. Short-chain fatty acids dilate isolated human colonic resistance arteries. Gut 31, 1391-1394

Munoa F.J., Pares R., 1988. Selective medium for the isolation and enumeration of Bifidobacterium spp. Appl. Environ. Microbiol. 54, 1715-1718

Piva A., Morlacchini M., Casadei G., Gatta P.P., Biagi G., Prandini A., 2002. Sodium butyrate improves growth performance of weaned piglets during the first period after weaning. Ital. J. Anim. Sci. 1, 35-41

Tracey K.J., Morgello S., Koplin B., Fahey 3rd T.J., Fox J., Aledo A., Manogue KR., Cerami A., 1990. Metabolic effects of cachectin/tumor necrosis factor are modified by site of production. Cachectin/tumor necrosis factor-secreting tumor in skeletal muscle induces chronic cachexia, while implication in brain induces predominantly acute aborexia. J. Clin. Invest. 86, 2014-2024

Witte W., Jorsal S.E., Roth F.X., Kirchgessner M., Göransson L., Lange S., Pedersen K.B., 2000. Future strategies with respect to the use of feed without antibiotic additives in pig production. Pig News Inform. 21, 27N-32N 